\title{
Ketimpangan Pelayanan Kesehatan Dasar dan Ekonomi di Wilayah Perbatasan
}

\author{
Inequality of Basic and Economic Health Services in the Border Region
}

\section{Cucu Herawati ${ }^{1}$, Syaeful Bakhri ${ }^{2}$}

\author{
${ }^{1}$ Program Studi Kesehatan Masyarakat STIKes Cirebon \\ ${ }^{2}$ Fakultas Syariah dan Ekonomi Islam IAIN Syekh Nurjati Cirebon \\ email : ${ }^{1}$ cucue_herawatie@yahoo.co.id, ${ }^{2}$ sultan01aulia@yahoo.com
}

\begin{abstract}
Abstrak
Permasalahan pembangunan di Indonesia saat ini bukan hanya pada sektor pendidikan saja, tetapi juga pada sektor ekonomi dan sektor kesehatan. Rasio Puskesmas terhadap penduduk di Kabupaten Cirebon $1:$ 40.289. Laju Pertumbuhan Ekonomi (LPE) Kabupaten Cirebon masih fluktuatif, dibandingkan di Kota Cirebon setiap tahunnya mengalami kenaikan. Tujuan penelitian ini untuk mengkaji aksesbilitas masyarakat terhadap pelayanan publik dasar bidang kesehatan dan ekonomi pasar tradisional.

Metode penelitian menggunakan jenis penelitian deskriptif dengan desain Cross sectional. Lokasi penelitian di wilayah perbatasan Kabupaten Cirebon, Sampel dalam penelitian sebanyak 280 responden. Analisis data dengan distribusi frekwensi, analisis Gap, dan studi komparasi.

Hasil penelitian menjelaskan bahwa kemudahan akses terhadap fasilitas kesehatan sebagian besar responden menyatakan puas $(35,4 \%)$, sarana prasarana $28,2 \%$ tidak puas, kemampuan petugas cukup puas $(41.4 \%)$, kepastian waktu pelayanan $32,1 \%$ tidak puas, kemudahan melakukan komunikasi 25,4\% tidak puas, kebijakan Pemerintah terhadap pembiayaan kesehatan tidak puas $(27,9 \%)$, dan perbandingan pelayanan kesehatan menunjukkan tidak puas $(33,9 \%)$. Adanya GAP pelayanan kesehatan dasar sebesar 10,8. Didapatkan 1 pasar tradisional di Kabupaten Cirebon melayani 66.968 penduduk, sedangkan untuk kota Cirebon 1 pasar melayani 38.811 .

Saran yang diusulkan sebaiknya Pemerintah melakukan perbaikan terhadap peningkatan mutu pelayanan kesehatan dasar dan penambahan pasar tradisional baru sebagai entitas ekonomi yang akan menghidupkan perekonomian masyarakat.
\end{abstract}

Keywords: Pelayanan Dasar, Kesehatan, Ekonomi.

\footnotetext{
Abstract

Current development problems in Indonesia are not only in the education sector but also in the economic and health areas. The ratio of Puskesmas to residents in Cirebon Regency 1: 40,289. The economic growth rate (LPE) of Cirebon Regency is still volatile, compared to the increase in the city of Cirebon. The purpose of this study is to examine the accessibility of society to essential public services in the health and traditional market economies.
}

The research method uses a descriptive research type with a cross-sectional design. The research location in the border area of Cirebon Regency, the sample in the study were 280 respondents. Data analysis with frequency distribution, Gap analysis, and comparative studies.

The results of the study explained that the ease of access to health facilities of the majority of respondents expressed satisfaction $(35.4 \%)$, infrastructure facilities $28.2 \%$ were not satisfied, the ability of officers was quite satisfied (41.4\%), certainty of service time $32.1 \%$ dissatisfied, convenience communication $25.4 \%$ were dissatisfied, Government policy towards health financing was not happy $(27.9 \%)$, and comparison of health services showed dissatisfaction (33.9\%). The existence of GAP essential health services amounted to 10.8. Obtained one traditional market in Cirebon District serving 66,968 residents, while for Cirebon city one market served 38,811 .

The suggestion suggested that the Government should make improvements to the improvement of the quality of essential health services and the addition of new traditional markets as economic entities that will revive the economy of the community.

\section{Keywords: Basic Services, Health, Economy.}

\section{Pendahuluan}

Kabupaten Cirebon berbatasan dengan Kabupaten Brebes Provinsi Jawa Tengah dan daerah lain di Jawa Barat. Persebaran penduduk di Kabupaten Cirebon tidak merata. Menurut tingkat kepadatan, wilayah dengan kecamatan terpadat yaitu Kecamatan Weru $\left(7.335 / \mathrm{m}^{2}\right)$, Kedawung $\left(6.985 / \mathrm{m}^{2}\right)$, Plered $\left(4.956 / \mathrm{m}^{2}\right)$ dan Tengah Tani $\left(4.790 / \mathrm{m}^{2}\right)$. Kepadatan penduduk adalah salah satu faktor risiko penyebab terjadinya penyebaran penyakit menular yang berbasis lingkungan seperti Infeksi Pernafasan, Demam Berdarah Dengue, Tuberculosis Paru dan lainnya. Indeks Pertumbuhan Manusia (IPM) Kabupaten dan Kota Cirebon 
berdasarkan data BPS Kabupaten dan Kota Cirebon, ditemukan indikasi adanya ketimpangan, terbukti bahwa di tahun 2014 IPM Kabupaten Cirebon hanya sebesar 66\% sementara Kota Cirebon sudah memiliki IPM $73,3 \%$ pada tahun yang sama. Selanjutnya pada tahun 2015 IPM Kabupaten Cirebon mengalami peningkatan menjadi $66,7 \%$, namun Kota Cirebon juga mengalami peningkatan pada tahun 2015 mencapai angka IPM sebesar $73,7 \% .^{1}$ Banyak hal yang menjadi faktor dalam mempengaruhi belum meratanya pembangunan, diantaranya kurangnya partisipasi masyarakat, pola perencanaan pembangunan mengartikan makna partisipasi sebagai bentuk dukungan rakyat terhadap satuan rencana pembangunan yang sebelumnya telah dirancang, kurangnya sumber daya manusia. ${ }^{2}$.

Meskipun secara nasional kualitas kesehatan mengalami peningkatan namun disparitas antar kawasan, antar tingkat ekonomi dan antar perkotaan dan pedesaan masih cukup tinggi. ${ }^{3}$ Ketersediaan supply tenaga serta fasilitas pelayanan kesehatan di Indonesia menunjukkan kesenjangan antara wilayah kabupaten dan kota. Persebaran tenaga dokter baik dari aspek jumlah maupun rasio masih lebih banyak di kota, namun demikian distribusi jumlah dan rasio bidan lebih banyak di kabupaten daripada di kota ${ }^{4}$. Ketersediaan fasilitas kesehatan di Kota jauh lebih bagus dari pada di Kabupaten pada indikator jumlah rumah sakit (pemerintah dan swasta), total tempat tidur tersedia, maupun rasio tempat tidur dibanding dengan jumlah penduduk. ${ }^{4}$

Sarana pelayanan kesehatan pemerintah di Kabupaten Cirebon pada tahun 2014 terdiri dari Puskesmas 57 buah, dengan rincian 8 (delapan) puskesmas dengan tempat perawatan (DTP) dan 49 tanpa perawatan. Memiliki jejaring Puskesmas pembantu sebanyak 69 buah yang tersebar di 40 kecamatan. Selain Puskesmas ada 2 (dua) rumah sakit, rumah sakit umum milik daerah dan 1 (satu) Rumah Sakit Khusus Paru milik Pemerintah Provinsi Jawa Barat.
Puskesmas yang mrupakan ujung tombak dalam pemberian pelayanan kesehatan diupayakan dapat menjangkau masyarakat di semua wilayah dengan berbagai kondisi. Rasio Puskesmas terhadap penduduk 1 : 40.289, artinya setiap 40.289 penduduk terdapat 1 puskesmas. Rasio puskesmas terhadap penduduk yang ideal adalah 1 banding 25.000 sampai dengan 30.000. Capaian Angka Harapan Hidup (AHH) pada tahun 2012 sebesar 65,52 tahun dan tahun 2013 mencapai 66,04 tahun. $^{5}$

Sesuai dengan amanat undang-undang No.32 tahun 2004 tentang otonomi daerah, Otonomi daerah merupakan wewenang, hak serta kewajiban pada daerah otonom tertentu dengan tujuan mengurus serta mengatur sendiri urusan pemerintahan yang berkaitan dengan kepentingan masyarakat setempat sesuai dengan kaidah pada perundang-undangan yang berlaku. Sehingga segala kebutuhan masyarakat merupakan kewajiban pemerintah daerah untuk memenuhinya. Tetapi pada kenyataannya, masih banyak ditemukan adanya pemenuhan kebutuhan suatu daerah dipenuhi oleh daerah lain, khususnya kawasan yang berbatasan. Misalnya penggunaan sarana pelayanan kesehatan milik Kota Cirebon banyak digunakan oleh masyarakat Kabupaten Cirebon di kawasan perbatasan, contohnya Kecamatan Kedawung yang berbatasan dengan Kecamatan Kejaksan dan Kecamatan Kesambi Kota Cirebon, ini dikarenakan Kecamatan Kedawung merupakan salah satu wilayah terpadat dan jarak fasilitas kesehatan lebih dekat dengan Kota Cirebon. Padahal pelayanan publik tidak bisa dipisahkan, mengingat ekspektasi dan persepsi terkadang tidak berjalan beriringan atau bahkan mungkin berlawanan dan pada akhirnya sering menimbulkan kesenjangan. ${ }^{6}$

Selain faktor jarak dan aksesbilitas penyebab adanya pelayanan lintas batas daerah juga disebabkan karena pelayanan lebih lengkap (tenaga dan peralatan kesehatan) dari tempat tinggalnya. $^{7}$ Infrastruktur berperan menjadi 
salah satu komponen fisik utama bagi wilayah perbatasan mengingat pengembangan infrastruktur yang sistematis, terarah dan juga konsisten akan mampu mengarahkan pada peningkatan kesejahteraan masyarakat pada kawasan perbatasan. Ketersediaan pelayanan kesehatan dan sarana pendukung masih rendah karena persebarannya kurang merata dibandingkan dengan Kota. $^{8}$ Pembangunan infrastruktur di wilayah perbatasan meliputi fasilitas pendidikan, fasilitas kesehatan, jalan, transportasi serta fasilitas lainnya menunjukkan perkembangan yang signifikan tetapi belum mencapai apa yang diharapkan dan masih terkesan lamban. ${ }^{9}$

Salah satu indikator sebuah daerah bergerak maju adalah dapat dilihat dari Laju Perumbuhan Ekonomi (LPE). Ada pergerakan LPE yang berbeda antara Kabupaten Cirebon dengan Kota Cirebon, berdasarkan data pada tabel 1 di bawah ini dimana LPE Kabupaten Cirebon dinilai masih fluktuatif dengan nilai persentase terbesar ditemukan pada tahun 2016 yaitu hanya sebesar $5,62 \%$. Lain halnya yang terjadi pada LPE Kota Cirebon yang setiap tahunnya terus mengalami kenaikan secara positif hingga pada tahun 2016 LPE nya $5,95 \%$. Hal tersebut menggambarkan fakta bahwa telah terjadi ketimpangan pada laju pertumbuhan ekonomi Kabupaten dan Kota Cirebon.

Tabel 1. Perbandingan Laju Pertumbuhan Ekonomi Kabupaten dan Kota Cirebon Tahun 2013 - 2016 (Persen)

\begin{tabular}{lcccc}
\hline Kabupaten & \multicolumn{4}{c}{ Laju Pertumbuhan Ekonomi } \\
\cline { 2 - 5 } \multicolumn{1}{c}{ Kota } & $\mathbf{2 0 1 3}$ & $\mathbf{2 0 1 4}$ & $\mathbf{2 0 1 5} *$ & $\left.\mathbf{2 0 1 6}^{* *}\right)$ \\
\hline $\begin{array}{l}\text { Kabupaten } \\
\begin{array}{l}\text { Cirebon } \\
\text { Kota }\end{array}\end{array}$ & 4,96 & 5,07 & 4,88 & 5,62 \\
Cirebon & 4,90 & 5,71 & 5,81 & 5,95 \\
\hline
\end{tabular}

Sumber: BPS Kabupaten dan Kota Cirebon, 2017 (data diolah)

Salah satu indikator pelayanan dasar pada bidang ekonomi oleh suatu daerah adalah keberadaan pasar pada daerah tersebut, terutama keberadaan pasar tradisional sebagai nadi dan gerak tumbuh perekonomian masyarakat. Dengan jumlah penduduk Kabupaten Cirebon pada tahun 2016 sebesar 2.143.000 jiwa, yang hanya memiliki 8 (delapan) pasar tradisional yang dikelola Pemda Kabupaten Cirebon, meliputi pasar Ciledug, pasar Babakan, pasar Cipeujeuh, pasar Sumber, pasar Palimanan, pasar Weru (Kue), pasar Pasalaran dan pasar Jamblang. Di Kabupaten Cirebon juga terdapat juga pasar desa sebanyak 24 buah pasar. Sementara Kota Cirebon yang berpenduduk 310.486 jiwa pada tahun 2016.memiliki 8 (delapan) pasar tradisional, meliputi pasar Kanoman, pasar Pagi, pasar Jagasatru, pasar Kramat, pasar Drajat, pasar Perumnas, pasar Harjamukti Kalitanjung, dan pasar Gunungsari.

Tujuan dari penelitian ini yaitu untuk mengkaji aksesbilitas masyarakat terhadap pelayanan publik dasar bidang kesehatan dan bidang ekonomi di Kabupaten dan Kota Cirebon terutama di kawasan perbatasan guna meningkatkan pemerataan fasilitas pelayanna publik sekaligus meningkatkan taraf hidup masyarakat.

\section{Metode Penelitian}

Penelitian ini merupakan jenis penelitian deskriptif dengan desain Cross sectional, dimana data dikumpulkan pada waktu yang sama antara faktor risiko dan akibat. ${ }^{10}$ Pengumpulan data dengan wawancara menggunakan instrumen sebagai panduan wawancara dan telaah dokumen/literatur untuk memperolah data sekunder. Lokasi penelitian ini dilakukan di wilayah perbatasan Kabupaten Cirebon dan Kota Cirebon, yaitu: Kecamatan Kedawung, Kecamatan Mundu, Kecamatan Talun dan Kecamatan Gunungjati. Sampel dalam penelitian ini sebanyak 280 responden dengan rincian setiap kecamatan diambil 70 responden. Teknik pengambilan sampling yaitu Cluster sampling, diantaranya kecamatan yang terpilih sebagai sampling berdasarkan atas pertimbangan geografis wilayah perbatasan Kabupaten Cirebon. Analisis data dengan 
distribusi frekwensi, analisis Gap untuk menilai seberapa besar kesenjangan antara kinerja aktual dengan sesuatu yang diharapkan terhadap pelayanan kesehatan di Wilayah Perbatasan dan studi komparatif terhadap keberadaan akses pelayanan dasar ekonomi

\section{Hasil}

Hasil penelitian ini berasal dari 280 responden dengan metoda pengumplan data wawancara dilaksanakan di wilayah perbatasan Kabupaten Cirebon dan Kota Cirebon, yaitu: Kecamatan Kedawung, Kecamatan Mundu, Kecamatan Talun dan Kecamatan Gunungjati. Dimana setiap kecamatan diambil 70 responden. Teknik pengambilan sampling yaitu
Cluster sampling. Variabel yang disajikan dihasil penelitian ini yaitu aksesibilitas masyarakat pelayanan publik dasar bidang pelayanan kesehatan yang meliputi: (kemudahan akses terhadap fasilitas kesehatan, ketersediaan sarana dan prasarana fasilitas kesehatan, kemampuan petugas kesehatan dalam memberikan pelayanan, kepastian waktu dalam memperoleh pelayanan kesehatan, kemudahan melakukan komunikasi dalam pelayanank, kebijakan Pemerintah terhadap pembiayaan kesehatan, perbandingan pelayanan kesehatan dengan pelayanan Kota), Analisis GAP pelayanan kesehatan di Wilayah perbatasan, dan analisis komparasi pelayanan di Pasar Tradisional Tahun 2018.

\section{Aksesibilitas Masyarakat Pelayanan Publik Dasar Bidang Pelayanan Kesehatan}

Berikut adalah gambaran penilaian masyarakat terhadap terkait aksesibilitas pelayanan kesehatan dasar di wilayah perbatasan:

Tabel 2. Aksesibitas Pelayanan Kesehatan Dasar

\begin{tabular}{|c|c|c|}
\hline \multirow[b]{2}{*}{ Keterangan } & \multicolumn{2}{|c|}{ Kinerja } \\
\hline & Frekuensi & Persen \\
\hline \multicolumn{3}{|c|}{ Kemudahan Akses Terhadap Fasilitas Kesehatan } \\
\hline Sangat tidak puas & 18 & 6,4 \\
\hline Tidak puas & 66 & 23,6 \\
\hline Cukup puas & 91 & 32,5 \\
\hline Puas & 99 & 35,4 \\
\hline Sangat puas & 6 & 2,1 \\
\hline Total & 280 & 100 \\
\hline
\end{tabular}

\section{Ketersediaan Sarana dan Prasarana Fasilitas Kesehatan}

Sangat tidak puas

Tidak puas

Cukup puas

Puas

Sangat puas

Total

280

100

\section{Kemampuan petugas kesehatan dalam memberikan pelayanan}

Sangat tidak puas

23

Tidak puas
63 


$\begin{array}{lccc}\text { Cukup puas } & & 116 & 41,4 \\ \text { Puas } & 72 & 25,7 \\ \text { Sangat puas } & \text { Total } & 6 & 2,1 \\ & & \mathbf{2 8 0} & \mathbf{1 0 0}\end{array}$

\section{Kepastian waktu dalam memperoleh pelayanan kesehatan}

Sangat tidak puas

Tidak puas

$90 \quad 32,1$

Cukup puas

$83 \quad 29,6$

Puas

Sangat puas

$$
5
$$

\section{Kemudahan Melakukan Komunikasi dalam Pelayanan Kesehatan}

Sangat tidak puas

25

8,9

Tidak puas

Cukup puas

102

36,4

Puas

64

22,9

Sangat puas

18

6,4

Total

280

100

\section{Kebijakan Pemerintah Terhadap Pembiayaan Kesehatan}

Sangat tidak puas

19

6,8

Tidak puas

78

27,9

Cukup puas

84

30,0

Puas

77

27,5

Sangat puas

Total

280

100

\section{Perbandingan Pelayanan Kesehatan dengan Pelayanan Kota}

Sangat tidak puas

42

Tidak puas

Cukup puas

79

28,2

Puas

Sangat puas

Hasil Survey,2018

Berdasarkan tabel 2. didapatkan bahwa kemudahan akses terhadap fasilitas kesehatan di wilayah perbatasan sebagian besar responden menyatakan puas $(35,4 \%)$ dan tidak puas $(23,6 \%)$, sarana prasarana fasilitas pelayanan kesehatan responden yang menyatakan cukup puas $(36,1 \%)$ dan $28,2 \%$ tidak puas, kemampuan petugas kesehatan mengenai keterampilan didapatkan cukup puas (41.4\%) dan 22,5\% responden tidak puas, 
kepastian waktu pelayanan kesehatan terdapat $32,1 \%$ responden menyatakan tidak puas dan $29,6 \%$ puas, kemudahan melakukan komunikasi menyatakan cukup puas $36,4 \%$ dan tidak puas $(25,4 \%)$, kebijakan Pemerintah terhadap pembiayaan kesehatan didapatkan cukup puas $(30,0 \%)$ dan tidak puas $(27,9 \%)$, tingkat pelayanan kesehatan di Kabupaten Cirebon dibandingkan dengan pelayanan kesehatan Kota Cirebon didapatkan responden yang menyatakan cukup puas $(28,2 \%)$ dan tidak puas $(33,9 \%)$.

\section{Analisis GAP Pelayanan Kesehatan di Wilayah Perbatasan}

Berikut ini adalah temuan data analisis GAP terkait pelayanan kesehatan di wilayah perbatasan:

Tabel 3. Analisis GAP Pelayanan Kesehatan di Wilayah Perbatasan

\begin{tabular}{cccc}
\hline Bidang & Kenyataan & Harapan & Gap \\
\hline Pelayanan Kesehatan & 20,33 & 31,11 & 10,8
\end{tabular}

\section{Hasil Survey, 2018}

Berdasarkan tabel 3. hasil perhitungan analisis GAP pelayanan kesehatan, menunjukkan angka kenyataan pelayanan sebesar 20,33 dan harapan masyarakat sebesar 31,11 sehingga terjadi gap sebesar 10,8.

\section{Analisis Komparasi Pelayanan di Pasar Tardisional Tahun 2018}

Adapun rincian data komparasi pelayanan pasar tradisional pada Kota dan Kabupaten Cirebon, dapat diketahui pada tabel berikut:

Tabel 4. Analisis Komparasi Pelayanan di Pasar Tardisional Tahun 2018

\begin{tabular}{lccll}
\hline \multicolumn{1}{c}{ Keterangan } & $\begin{array}{c}\text { Jumlah } \\
\text { Penduduk }\end{array}$ & $\begin{array}{c}\text { Jumlah } \\
\text { Pasar Pemda }\end{array}$ & $\begin{array}{c}\text { Jumlah } \\
\text { Pasar Desa }\end{array}$ & Rasio Pelayanan \\
\hline Kota Cirebon & 310.485 & 8 & 0 & 38.811 \\
Kabupaten Cirebon & $2.143,000$ & 8 & 24 & 66.968 \\
\hline
\end{tabular}

\section{Hasil Survey,2018}

Jika dibandingkan antara jumlah penduduk yang ada di kabupaten Cirebon yaitu sebanyak 2.143.000 penduduk, dengan jumlah pasar sebanyak 8 pasar Pemda ditambah 24 pasar desa, maka dianalogikan 1 pasar tradisional melayani 66.968 penduduk, sedangkan untuk Kota Cirebon dengan jumlah penduduk hanya 310.486 dengan memiliki 8 pasar maka 1 pasar melayani 38.811 .

\section{Pembahasan}

Menurut Undang-Undang Nomor 36 tahun 2009 Pelayanan kesehatan adalah suatu alat dan/atau tempat yang digunakan untuk menyelenggarakan upaya pelayanan kesehatan, baik promotif, preventif, kuratif maupun rehabilitatif yang dilakukan oleh pemerintah, pemerintah daerah, dan/atau masyarakat. ${ }^{11}$ Aspek kesehatan menciptakan masyarakat produktif. Berdasarkan data di lapangan menunjukkan bahwa kemudahan akses terhadap fasilitas kesehatan yang ada di wilayah perbatasan sebagian besar responden menyatakan tidak puas $(23,6 \%)$. Ketidakpuasan ini diantaranya disebabkan jarak antara puskesmas dengan perumahan masyarakat sulit dijangkau oleh masyarakat. Dari sisi biaya transportasi, untuk datang ke puskesmas harus mengeluarkan biaya ojek sebesar Rp. $20.000,-$. Sementara, fasilitas sarana prasarana 
untuk mobilitas petugas puskesmas cukup terbatas sehingga pelayanan puskesmas sulit menjangkau masyarakat.

Ketersediaan sarana dan prasarana pelayanan kesehatan yang memadai menjadi pendukung kelancaran pelayanan kesehatan. Selain faktor jarak dan aksesbilitas penyebab adanya pelayanan lintas batas daerah juga disebabkan karena pelayanan lebih lengkap (tenaga dan peralatan kesehatan) dari tempat tinggalnya. ${ }^{[7,3]}$

Hasil temuan di lapangan menunjukkan bahwa responden di wilayah perbatasan menyatakan cukup puas $(36,1 \%)$, terhadap sarana prasarana fasilitas pelayanan kesehatan yang tersedia dan $28,2 \%$ responden menyatakan tidak puas. Ketidakpuasan ini didasarkan kepada kualitas pemeriksaan kesehatan umum, kebidanan dan gigi, hal ini merujuk pada keterbatasan fasilitas dan tenaga medis. Selain itu, kondisi kendaraan ambulan dan puskesmas keliling yang ada saat ini sebagian besar dalam kondisi rusak. Persediaan obat di Puskesmas masih terbatas, dan tidak adanya fasilitas untuk pemusnahan sampah medis disetiap puskesmas. Peran infrastruktur menjadi salah satu komonen fisik yang penting bagi wilayah perbatasan karena pengembangan infrastruktur yang sistematis, konsisten dan terarah akan mengarah pada peningaktan kesejahteraan masyarakat perbatasan. Ketersediaan pelayanan kesehatan dan sarana pendukung masih rendah karena persebarannya kurang merata dibandingkan dengan Kota. ${ }^{8}$

Kemampuan petugas kesehatan mengenai keterampilan di wilayah perbatasan Kabupaten Cirebon menyatakan tidak puas sebesar $22,5 \%$ responden. Ketidakpuasan ini disebabkan antara lain keterbatasan jumlah tenaga medis terutama dokter umum, dokter anak dan dokter gigi. Pembagian tugas pada staf dan tenaga fungsional kesehatan di puskesmas masih tumpang tindih sehingga tidak fokus pada pelayanan kesehatan kepada pasien. Kepastian waktu pelayanan mencerminkan standar minimal tingkat pelayanan yang baik, didapatkan sebanyak $32,1 \%$ responden yang menyatakan tidak puas dan 29,6\% menjawab puas, hal ini tercermin dari jadwal tetap pelayanan puskesmas yang diinformasikan kepada seluruh masyarakat yaitu setiap hari Senin hingga Sabtu, mulai pukul 07.00 sampai dengan pukul 13.00, kecuali pelayanan hari Sabtu hingga pukul 12.00. Kepastian waktu pelayanan kesehatan sebagian masyarakat menyatakan tidak puas, hal ini berkaitan dengan pelayanan administrasi kesehatan untuk rujukan ke rumah sakit. Kebijakan administrasi pelayanan kesehatan antara puskesmas dan rumah sakit masih belum sinergi dengan baik terutama terhadap pasien yang memiliki kartu BPJS kesehatan.

Komunikasi dapat menjadi instrumen untuk mengalirkan informasi regulasi, kebijakan, dan kondisi pelayanan kesehatan. Komunikasi yang baik akan memberikan transfer pemahaman kepada masyarakat penerima manfaat layanan. Berkenaan dengan hal tersebut, hasil temuan lapangan menunjukkan responden menyatakan cukup puas sebanyak $36,4 \%$, hal ini diperoleh dari penyebaran informasi baik melalui lisan maupun tertulis di beberapa papan informasi, media cetak lokal, dan media elektronik. Namun demikian, ada responden yang merasa tidak puas yaitu sebanyak $25,4 \%$ dan sangat tidak puas sebanyak $8,9 \%$. Hal ini dapat disebabkan karena dinamika informasi kebijakan pelayanan kesehatan yang berbeda dengan pelaksanaan di lapangan dan keterbatasan kemampuan masyarakat dalam menyerap informasi. Aspek kesehatan menjadi hak dasar atas setiap warga negara, berbagai kebijakan telah, sedang, dan akan dirumuskan untuk penyelenggaraan pelayanan kesehatan termasuk didalamnya adalah kebijakan pembiayaan kesehatan.

Pemerintah harus menanggung pembiayaan kesehatan yang cukup sehingga pelayanan kesehatan dapat mudah, terjangkau, dan 
berkualitas. Baik tidaknya kualitas jasa tergantung pada kemampuan penyedia jasa dalam memenuhi harapan pelanggannya secara konsisten. ${ }^{12}$ Responden menyatakan kondisi pelaksanaan kebijakan pemerintah terhadap pembiayaan kesehatan menunjukkan rasa cukup puas $(30,0 \%)$ dan tidak puas $(27,9 \%)$. Ketidakpuasan ini disebabkan oleh pembiayaan pelayanan kesehatan di Kabupaten Cirebon masih dipungut biaya. Sementara, pelayanan kesehatan di Kota Cirebon sudah gratis. Ada kecemburan sosial yang terjadi di wilayah perbatasan. Pelayanan kesehatan adalah sub sistem pelayanan kesehatan yang tujuan utamanya adalah pelayanan preventif (pencegahan) dan promotif (peningkatan kesehatan ) dengan sasaran masyarakat. ${ }^{13}$

Dua faktor utama yang mempengaruhi kualitas pelayanan yaitu respected service dan perceived service. Apabila jasa yang diterima atau dirasakan (perceived service) sesuai dengan yang diharapkan, maka kualitas jasa dipersepsikan sebagai kualitas ideal. Sebaliknya jika jasa yang diterima lebih rendah daripada yang diharapkan, maka kualitas jasa yang dipersepsikan buruk. $^{12}$ Berdasarkan penilaian responden di wilayah perbatasan, tingkat pelayanan kesehatan di Kabupaten Cirebon dibandingkan dengan pelayanan oleh Kota Cirebon menunjukkan tanggapan responden merasa cukup puas $(28,2 \%)$ dan tidak puas $(33,9 \%)$.

Dominasi ketidakpuasan pelayanan kesehatan mengindikasikan keberadaan sarana dan prasarana sebagian besar Puskesmas kurang memadai, sistem pelayanan rujukan Kabupaten Cirebon prosesnya lama, akses jalan masih sulit dijangkau masyarakat. Keterbatasan tenaga medis seperti dokter umum dan dokter gigi sehingga banyak tugas pokok yang rangkap. Sedangkan, pelayanan kesehatan ditingkat Puskesmas di Kota Cirebon sudah ada pelayanan dokter spesialis secara berkala. Hal ini belum tersedia di Kabupaten Cirebon. Hasil analisis ini juga diperkuat oleh hasil kajian empiris sebelumnya, yaitu Zakiyah (2006) yang menyatakan berdasarkan hasil temuannya bahwa masih banyaknya service gap (kesenjangan pelayanan) yang terjadi di wilayah perbatasan Kalimantan. ${ }^{14}$

Kesenjangan tersebut disebabkan oleh kurang efektifnya lembaga yang menjalankan perannya dalam melayani masyarakat, ditambah dengan terjadinya disfungsi pelayanan tertentu termasuk pelayanan kesehatan yang diakibatkan oleh belum adanya lembaga yang mampu menangani di wilayah perbatasan. Hal yang dapat ditempuh untuk meningkatkan pelayanan kepada masyarakat menurut Utomo (2006) adalah dengan meningkatkan pola kerjasama serta memiliki korelas positif antar kelembagaan penyelenggara pembangunan atau pelayanan masyarakat, disamping tujuan utamanya untuk meningkatkan pelaanan kepada masyarakat, model - model kerjasama antar daerah juga dapat menjadi metode yang efektif untuk mengatasi keterbatasan sektor publik, terutama dalam aspek SDM dan Anggaran. ${ }^{15}$

Pembangunan infrastruktur di daerah perbatasan meliputi jalan, fasilitas pendidikan, fasilitas kesehatan, transfortasi, pasar tradisonal dan fasilitas lainnya menunjukkan perkembangan yang signifikan tetapi belum mencapai apa yang diharapkan dan masih terkesan lamban. ${ }^{9}$ Pertumbuhan ekonomi adalah satu dari beberapa indikator penting yang digunakan untuk mengukur kinerja perekonomian suatu negara. Negara tentu akan mengalami kemajuan ketika mampu menicptakan keadilan, kesejahteraan sosial melalui pertumbuhan yang positif. Namun disisi lain, pembangunan yang hanya berorientasikan kepada pertumbuhan ekonomi semata dapat menjadi potensi lahirnya ketidakadilan yang menyebabkan adanya kesenjangan dalam kehidupan bermasyarakat. Oleh karenanya pertumbuhan ekonomi dengan sendirinya tidak cukup mampu dianggap sebagai tujuan akhir suatu pembangunan. ${ }^{16}$ Tantangan utama dalam pembangunan 
Indonesia sekarang maupun dimasa mendatang adalah mencegah dan melakukan persiapan dini sekaligus mengatasi persoalan kesenjangan yang tidak hanya terjadi dalam dimensi antar perorangan, rumah tangga tetapi juga wilayah.

Salah satu indikator pelayanan dasar yang mampu mempengaruhi pertumbuhan ekonomi suatu daerah adalah keberadaan sarana niaga yaitu pasar baik untuk memenuhi ketersediaan kebutuhan primer maupun sekunder pada daerah tersebut, terutama keberadaan pasar tradisional sebagai nadi dan gerak tumbuh perekonomian masyarakat. Sebagaimana berdasarkan hasil temuan lapangan, jika dibandingkan antara jumlah penduduk yang ada di kabupaten Cirebon yaitu sebanyak 2.143.000 penduduk, dengan jumlah pasar sebanyak 8 pasar Pemda ditambah 24 pasar desa, maka dianalogikan 1 pasar tradisional melayani 66.968 penduduk, sedangkan untuk Kota Cirebon dengan jumlah penduduk hanya 310.486 dengan memiliki 8 pasar maka 1 pasar melayani 38.811. Berdasarkan penjelasan tersebut dapat ditemukan fakta bahwa telah terjadi kesenjangan pelayanan publik di Kabupaten dengan Kota Cirebon. Lebih dari itu, kesenjangan juga menimpa pada masingmasing daerah baik di Kabupaten maupun Kota Cirebon, pernyataan ini didasarkan pada Keputusan Menteri Permukiman dan Prasarana Wilayah Nomor 534/KPTS/M/2001 tentang Pedoman Penentuan Standar Pelayanan Minimal Bidang Penataan Ruang, Perumahan dan Permukiman dan Pekerjaan Umum yang menetapkan bahwa ketentuan ideal pada tiap Kecamatan minimalnya tersedia 1 (satu) pasar untuk setiap 30.000 penduduk. Kesenjangan tersebut tentu saja semakin mencerminkan adanya ketidakadilan dalam pemerataan kesejahteraan masyarakat. ${ }^{17}$

Konsep kesejahteraan disini tidak hanya mencakup deskripsi perihal sebuah cara mengorganisasikan kesejahteraan atau pelayanan ekonomi, namun tepatnya adalah sebuah konsep normative ataupun sistem pendekatan ideal yang menekankan bahwa setiap individu harus mendapatkan pelayanan public sesuai dengan kebutuhan atas suatu bentuk pemenuhan hak setiap lapisan masyarakat. ${ }^{18}$ Adapun upaya yang dapat mereduksi kesenjangan tersebut adalah dengan berupaya secepat mungkin dalam pembuatan konsepsi yang kuat dan berlandaskan keadilan sosial yang tentu saja didukung dengan adanya dorongan dan mobilisasi dari seluruh lembaga terkait.

\section{Kesimpulan}

Berdasarkan hasil penelitian di atas didapatkan beberapa kesimpulan, yaitu:

1. Masih terdapat adanya ketidak puasan masyarakat terhadap akses pelayanan kesehatan dasar di wilayah perbatasan dalam bidang:

a. Kemudahan akses terhadap fasilitas kesehatan terdapat $25,4 \%$.

b. Sarana prasarana sebanyak $28,2 \%$.

c. Kemampuan petugas, terdapat $22,5 \%$.

d. Kepastian waktu pelayanan terdapat $32,1 \%$.

e. Kemudahan melakukan komunikasi terdapat $25,4 \%$.

f. Kebijakan Pemerintah terhadap pembiayaan kesehatan terdapat $(27,9 \%)$.

g. Perbandingan pelayanan kesehatan dengan pelayanan Kota Cirebon terdapat $(33,9 \%)$.

2. Adanya gap sebesar 10,8, antara kinerja pelayanan kesehatan dasar sebesar 20,33 dengan harapan masyarakat sebesar 31,11.

3. Pelayanan bidang ekonomi didapatkan 1 pasar tradisional di Kabupaten Cirebon melayani 66.968 penduduk, sedangkan untuk kota Cirebon 1 pasar melayani 38.811, sehingga pelayanan dasar ekonomi di Kota Cirebon lebih baik dibanding Kabupaten Cirebon.

\section{Saran}


Saran untuk penelitian lebih lanjut, sebaiknya yang dikaji tidak hanya pelayanan kesehatan dasar yang ada di Puskesmas saja, tetapi mencangkup pelayanan kesehatan lainnya seperti RS, adanya pengembangan variabel yang belum diteliti pada penelitian kali ini yang lebih disesuaikan dengan kebutuhan pelayanan kesehatan dasar masyarakat di Wilayah perbatasan Kabupaten Cirebon seperti sumber air bersih dan penangangan sampah, tidak hanya aspek bidang pelayanan pasar tradisional saja yang dikaji tetapi pasar non tradisional juga sebaiknya diteliti sebagai bahan perbadingan analisis.

\section{Daftar Pustaka}

1. Statistik, B. P. Kabupaten Cirebon Dalam Angka. (2015).

2. Junaedi H. Pembangunan di Pedesaan. (UI Perss, 1999).

3. Laksmiarti, T., Budisuari, M. A. \& Ardani, I. Pilihan Pelayanan Kesehatan Oleh Masyarakat Perbatasan Negara ( People' s Health Service Preference at the State Borders [ A Policy Analysis ]). Bul. Penelit. Sist. Kesehat. 17, 353-362 (2014).

4. Mubasyiroh, R., Nurhotimah, E. \& Laksono, A. D. Indeks Aksesibilitas Pelayanan Kesehatan di Indonesia. Aksesibilitas Pelayanan Kesehat. di Indones. 21-58 (2016).

5. Dinkes Kabupaten Cirebon (2018) Profil Kesehatan Kabupaten Cirebon.

6. Suryokusumo, F. Pelayanan Publik Dan Pengelolaan Infrastruktur Perkotaan. (Sinergi Publishing, 2008).

7. Semendawai, T. \& Wahyono, $H$. Pelayanan Kesehatan Lintas Batas Daerah Puskesmas Mranggen Di Kawasan Perbatasan Kota Semarang Dan Kabupaten Demak. J. Tek. PWK 3, 117-133 (2014).

8. Suharmiati, Laksono, A. D. \& Astuti, W. D. Review Kebijakan tentang pelayanan kesehatan Puskesmas di daerah terpencil perbatasan. Bul. Penelit. Sist. Kesehat. 16, 109-116 (2013).
9. Jesly, K. Pebangunan Infrastruktur Daerah Perbatasan. 4, 404-418 (2016).

10. Sastroasmoro S. \& Ismael S. Dasar-Dasar Metodelogi Penelitian Klinis. (CV Sagung Seto, 2016).

11. Farich, A. (2012) Manajemen Pelayanan Kesehatan. Yogyakarta: Gosyen Publishing.

12. Moenir, H. (2006) Manajemen Pelayanan Umum di Indonesia. Jakarta: Bumi Aksara.

13. Soekidjo, N. (2003) Pendidikan Dan Perilaku Kesehatan. 1st edn. Rineka Cipta.

14. Zakiyah, S. (2007) 'Kinerja Pelayanan Publik dan Kebutuhan Penataan Kelembagaan Pengelolaan Wilayah Perbatasan Di Kalimantan', Jurnal Borneo Administrator, 3(1), pp. 48-66. Available at:

https://doi.org/https://doi.org/10.24258/jba .v3i1.108.

15. Utomo, T. W. W. (2006) 'Prospek Pengembangan kerjasama Antar Daerah Kapubaten/Kota Di Kalimantan Timur Dalam Penyelenggaraan Urusan Pembangunan Dan Pelayanan Masyarakat', Jurnal Borneo Administrator, 2(1), pp. 67-87. Available at:

https://doi.org/https://doi.org/10.24258/jba .v2i1.17.

16. Sukwika, Tatan. (2018) 'Peran Pembangunan Infrastruktur Terhadap Ketimpangan Ekonomi Antarwilayah di Indonesia', Jurnal Wilayah dan Lingkungan, 6(2), pp. 115-130. Available at:

https://ejournal2.undip.ac.id/index.php/jwl /article/view/2277

17. Republik Indonesia. Keputusan Menteri Permukiman dan Prasarana Wilayah Nomor 534 / KPTS / M / 2001 tentang Pedoman Penentuan Standar Pelayanan Minimal Bidang Penataan Ruang, Perumahan dan Permukiman dan Pekerjaan Umum.

18. Nuriyanto. (2014) 'Penyelenggaraan 
Pelayanan Publik Di Indonesia, Sudahkah Berlandaskan Konsep "Welfare State"?', Jurnal Konstitusi, 11(3), pp. 428-453. Available at: http://ejournal.mahkamahkonstitusi.go.id/i ndex.php/jk/article/view/34. 